DOI: 10.33766/2524-0323.93.233-248

УДК 349.2

Кравченко І. М., кандидат юридичних наук, доиент каредри державно-правових дисииплін Луганського державного університету внутрішніх справ імені Е. О. Дідоренка, адвокат (м. Севєродонецьк, Украйна)

e-mail: inkravchenko2017@gmail.com

ORCID ID: https:/ /orcid.org/0000-0002-3082-4970

\title{
ПРОБЛЕМИ ПРАВОВОГО РЕГУЛЮВАННЯ КОНТРОЛЮ РОБОТОДАВЦЯМИ НАЙМАНИХ ПРАЩВНИКІВ ІЗ ЗАСТОСУВАННЯМ ТЕХНІЧНИХ ЗАСОБІВ $З$ ОГЛЯДУ НА ЗАХИСТ ЇХНІХ ПЕРСОНАЛЬНИХ ДАНИХ
}

На підставі аналізу норм національного законодавства, національної судової практики та практики ССПЛ у статті надано правову характеристику поняття «захист персональних даних» щодо допустимості меж обмеження конституційних прав і свобод працівників на їхнє приватне життя при здійсненні роботодавцем контролю із застосуванням технічних засобів та способів за виконанням ними трудових функцій. Вивчено питання можливості нормативного визначення можливих меж обмеження прав працівників на приватне життя під час виконанням ними своїх трудових функцій. Визначено, що ефективний захист права працівників на приватне життя (приватності особистої зони під час виконання ними трудових функцій), захист їхніх персональних даних не можливий без його нормативного регулювання з використанням практики ЄСПЛ.

Ключові слова: роботодавець; найманий працівник; робоче місце працівника; відеоспостереження; прослуховування працівника; контроль особистої кореспонденщії; персональні дані; конфіденційна інформація; обробка персональних даних; правомірне обмеження прав і свобод громадян.

Постановка проблеми. Стрімке поширення у світі цифрових технологій $\epsilon$ великим поштовхом до четвертої промислової революції, яка неодмінно і докорінно змінить економіку, промисловість, якісні та кількісні чинники ринків послуг і найманої праці, та, як наслідок, буде потужним викликом для розвитку трудових відносин, бо вони нададуть роботодавцю практично необмежену та всеосяжну можливість застосування спеціальних засобів контролю за найманими ним працівниками. Зазначене стає невід'ємною частиною таких відносин. Уже не виглядає утопічною, а скоріше, звичною, суть роману-антиутопії Джорджа Орвелла «1984», опублікованого ще у 1949 році, щодо можливості тотального стеження та/або контролю за людьми (George Orwell, 2004).

Поява нових форм та розвиток трудових відносин, а також життєво небезпечні явища і загрози для суспільства, неминуче призводять до нових викликів для прав людини, включаючи трудові. А отже, актуальною проблемою правового регулювання є визначення меж застосування технічних засобів контролю, а саме, межі між загальною громадською безпекою, як «суспільним благом», та приватним життям, як «особистим благом» конкретної людини. 
Технічна можливість зняття інформації з транспортних телекомунікаційних та електронних інформаційних мереж, публічні та приховані відеоспостереження і прослуховування, контроль за електронним листуванням та спілкуванням осіб у соціальних мережах тощо, з огляду на забезпечення державної і суспільної безпеки, стає невід'ємною частиною нашого сучасного життя. Проблема розширення сфер застосування спеціальних засобів контролю особливо гостро постала 3 огляду на антитерористичні («Zakon Ukrainy», 2003) й антиепідеміологічні заходи («Postanova Kabinetu Ministriv», 2020), які неможливо уявити без всеосяжного контролю за всім населенням держави та/або його окремих верств, практично у всіх сферах суспільного, а подеколи, й особистого життя, у т.ч. й на робочому місці працівників під час виконання ними трудових функцій.

Тож на часі $є$ створення такого правового механізму, за яким, роботодавець міг би контролювати виконання працівниками трудових обов' язків, у тому числі з використанням технічних засобів стеження, але при одночасному забезпеченні конституційних прав і гарантій працівників, включаючи право на їх особисту зону в момент виконання ними трудових обов'язків, не допускаючи при цьому дій, що принижують їхню честь і гідність (Rishennia ECHR, 2004), забезпечуючи захист персональних даних працюючих.

Тому постає дуже складна, але принципова проблема, аби персональні дані працюючих, й інформація, що отримана під час відеоспостереження; прослуховування їхніх телефонних розмов, що ведуться з корпоративних телефонних засобів зв' язку; спостереження за листуванням (електронною, телеграфною та іншою кореспонденцією); спостереження за їхнім спілкуванням у соціальних мережах та за допомогою інших заходів та засобів контролю за найманими працівниками, не мали б дискримінаційного характеру, яке на сьогодні має різні форми та прояви (Nesterovych, 2020), та не використовувалась би протиправно.

Аналіз останніх досліджень і публікацій. Окремі аспекти зазначеної проблеми ставали предметом дослідження вчених-фахівців різних галузей права. Так питання порушення роботодавцями права на повагу до приватного життя працівників розглядались О. Попазовою (Popazova, O.), Д. Мельником (Melnyk, D.), Р. Тополевським (Topolevskyj, R.), О. М. та О. В. Дроздовими (Drozdovy, O. M. \& O.V., 2018); щодо гарантування безпеки персональних даних працівника: І. Я. Кисельовим (Kiselyov, I.), M. В. Різак (Rizak, M.), М. В. Бем (Bem, M.), I. М. Городиським (Gorodusky, I.), Г. Саттоном (Satton, G.), О. М. Родіоненко (Rodionenko, О.) тощо; питання використання технічних засобів спостереження в трудових відносинах, перш за все, відеоспостереження на робочому місці та прослуховування працівників - М. М. Бурбики (Bubryka, M.), I. М. Вагановою (Vaganova, I., 2016), I. В. Шевчук (Shevchuk, I.), О. Кривецьким (Kryvetsky, О., 2020) тощо; проблеми щодо права на повагу та таємнищю кореспонденщії - О. А. Білічак (Bilichak, О.), Д. В. Бушковим (Bushkov, D.), I. А. Вєтуховою (Vetuhova, I., 2019), Д. Б. Сергеєвою (Serheieva, D.), I. Р. Смольковою (Smolkova, I.), Н. В. Устименко (Ustymenko, N.), О. О. Фат'яновим (Fat'ianov, O.), В. Федоренком, (Fedorenko, 2019), С. В. Шевчуком (Shevchuk, S.) та багато іншими.

Однак, заразом слід визнати, що комплексних досліджень щодо проблем із забезпечення права працівників на приватне життя (іхнню особисту зону в момент 
виконання трудових обов'язків) та пов'язані з цим проблеми збереження їхніх персональних даних, саме науковців-фахівців із трудового права, явно не достатньо.

Формулювання цілей. Враховуючи, що існує об'єктивна потреба в регламентації трудових правовідносин щодо контрольних повноважень роботодавця за виконанням найманими працівниками трудових обов' язків за допомогою технічних засобів, при забезпеченні реалізації їх конституційних прав і гарантій, включаючи право на особисту зону в момент виконання ними трудових функцій, метою цієї статті є комплексний науковий аналіз теоретичних і практичних проблем та формулюванні науково-обгрунтованих висновків і пропозищій щодо вдосконалення чинного та перспективного законодавства в зазначеній сфері права.

Виклад основного матеріалу. У сучасних умовах ринкової економіки роботодавці, і це природньо, зацікавлені в більш відповідальному ставленні працівників до їхніх обов'язків: ефективному використанні та збереженні майна і ресурсів підприємства, організації чи установи; раціональному та максимально корисному використанні ними робочого часу; забезпеченні комерційної таємнищі; дотриманню правил з охорони та гігієни їхньої праці; дотриманні виробничих процесів та трудової дисципліни тощо.

До того ж, користуючись падінням попиту на ринку праці, роботодавці зацікавлені в оптимізації процесу організації своєї роботи, включаючи використання праці найбільш підготовлених, відповідальних та цілком лояльних працівників. Тож зростатимуть вимоги роботодавця до найманого ним персоналу (від лат. persona - особистість) щодо виконання функціональних обов' язків: ефективному використанні та збереженні майна і ресурсів; раціональному та максимально корисному використанні робочого часу; забезпечення комерційної таємнищі; дотриманні виробничих процесів та трудової дисципліни тощо.

За цих умов адміністрація підприємства, організації, установи чи фізична особа-роботодавець будуть намагатися всебічно контролювати найманих працівників у межах робочого часу - як за їх «стаціонарними» робочими місцями, так і за робочими місцями, що організовані за дистанційним принщипом (Kodeks pratci, p. 24). Вважаючи, що приватне життя працівників на цей час не існує, роботодавці, на власний розсуд та зважаючи на власні фінансові можливості, застосовують щодо такого контролю різне: відеоспостереження, включаючи приховане; прослуховання та записи телефонних розмов корпоративними телефонами; спостереження за електронним листуванням та спілкуванням у соціальних мережах та інший збір особистих даних найманих ними працівників. Беззаперечно, новітні технології полегшують роботодавцю здійснювати контроль за працівниками, у тому числі й аспекти їхнього приватного життя, але ускладнюють працівникам можливість виявити цей контроль та захистити свої конституційні права.

Дисциплінарна (хазяйська) влада роботодавця, за визначенням I. В. Лазор, передбачає організацію найманої праці та керування нею, застосування правових та організаційних засобів забезпечення дотримання встановленого порядку на виробнищтві під час виконання найманими працівниками дорученої їм роботи. Причому, вказані повноваження роботодавця є не тільки доцільними, але й необ- 
хідними в умовах ринкових відносин (Lazor, p. 319-320). Вочевидь, під час реалізації таких керівних функцій своєї хазяйської (дисциплінарної) влади, роботодавець буде намагатись якомога більше контролювати працівників, включаючи застосування доступних технічних можливостей, притому, свідомо чи ні, обмежуючи їх права і свободи. Враховуючи об'єктивну нерівність між сторонами трудових відносин, означена проблема буде тільки поглиблюватись.

Водночас, сучасним правовим підгрунтям «приватності» працівників, тобто, їхню особисту зону в момент виконання ними трудових функцій, а отже, і зібрані під час контролю за ними персональні дані, є, перш за все, норми міжнародних актів (Konventsiia, 1950, p. 8-10), (Konventciia, 1981), (Hartiy, 2000, р. 8), які покладено в основу норм національного законодавства (Konstytutsiia Ukrainy, p. 28, 30, 31, 32), (Civilniy kodeks, p. 270, 271, 301, 302, 307). Не можемо погодитися $з$ позищією фахівців із цивільного права, які вважають «приватне життя» категорією, що не може існувати в рамках трудових правовідносин нібито через те, що основною метою встановлення систем контролю на місцях (перш за все, відеоспостереження), де зосереджується майно роботодавця є фіксація: фактів розкрадання як у робочий, так і в неробочий час; дій, які у подальшому можуть забезпечити власнику доказову базу у випадках спорів із контрагентами або особами, що вчинили корисливі правопорушення (Vaganova, 2016, р. 42). 3 огляду на зміст ст. 9 ЦК України, враховуючи, що норми чинного трудового законодавства України (як спеціальні) не регламентують відносини щодо контрольних повноважень роботодавця з використанням технічних засобів контролю та дотримання при тому прав працівників на ïx приватність, слід керуватися саме нормами цього Кодексу (Civilniy kodeks, p. 9). До того ж, виконуючи трудові функщії, працівник не втрачає гарантовані конституційні права і свободи людини, а отже, і право на свою приватність.

Ба більше, відповідно до Законодавства України (Konstytutsiia Ukrainy, p. 9), ("Zakon Ukrainy", 2004, p. 14, 15), ("Zakon Ukrainy", 2006, p. 17), норми міжнародного права (включаючи рішення ССПЛ) є джерелами права України. Проте одночасно, нормативне визначення «приватного життя», що дозволяло б визначити характер та обсяг інформації, що складає особисті (персональні) дані працівників під час виконання ними трудових функцій, у цих джерелах відсутні. Так у рішенні ССПЛ по справі «Пек проти Сполученого Королівства» зазначалось, що Конвенщія (Konventsiia, 1950) не розкриває змісту терміна «приватне життя», оскільки описує його як «термін з широким значенням, який не піддається визначенню» (Rishennia ECHR, 2003). Крім того, рішенням ССПЛ у справі «Німітц проти Німеччини» зазначалось, що було б занадто строго обмежити приватне життя інтимним колом, де кожен може жити своїм життям, як він вважає за краще, чим повністю виключити зовнішній світ із цього кола. Саме поняття «приватне життя» не може тлумачитися в обмежувальному значенні, бо повага до особистого життя має також включати, деякою мірою, право встановлювати і розвивати відносини з іншими людьми; не завжди можна провести чітке розмежування також і тому, що вести діяльність, яку можна віднести до професійної або ділової, можна з таким же успі- 
хом і зі свого місця проживання, і навпаки, можна займатися справами, які не належать до професійної сфери, в офісі або комерційних службових приміщеннях (Rishennia ECHR, 1992).

Таким чином, судові прецеденти ССПЛ визначають концепщію приватного життя працівника як сферу його безпосередньої особистої автономії, до якої належать аспекти моральної недоторканності та яка виходить за вузькі межі гарантій життя, вільного від небажаної публічності. 3 огляду на цю концепцію, ССПЛ вважає, що право на повагу до «приватного життя» включає фізичну і психологічну недоторканність людини. Причому, використання технічних засобів контролю 3 боку роботодавця носить примусовий характер та грунтується саме на психологічному впливі, який може бути легітимним, бо заснований на добровільному вольовому сприйнятті спостереження працюючим. Отже, працівник, усвідомлюючи наслідки свого рішення, вільний сам обирати, чи погоджуватися на контроль за виконанням ним трудових функцій за допомогою електронних засобів, чи ні.

Принциповим для сторін трудового договору є момент, з якого вводиться той чи інший вид контролю, до початку виконання працівником трудових функцій чи під час такого виконання, бо це безпосередньо впливає на зміну істотних умов праці, а відтак - на правові наслідки для сторін. 3 одного боку, укладання трудового договору буде залежати від того, чи дійшли сторони згоди за його істотними умовами (якщо ні - трудові відносини відсутні), з іншого боку, одностороння зміна умов діючої угоди про працю заборонена.

Так, відповідно до ч.2 ст. 22 Кодексу законів про працю України (далі - КЗпП України), при зміні трудового договору будь-яке пряме або непряме обмеження прав (контроль, як втручання до приватного життя працівника під час виконання ним трудових функцій, беззаперечно, є прямим обмеженням гарантованих йому Конституцією України прав) не допускається. А, відповідно до ч.3 ст. 38 цього Кодексу, працівник має право у визначений ним строк розірвати трудовий договір за власним бажанням, якщо власник або уповноважений ним орган не виконує законодавство про працю, умови колективного чи трудового договору (Kodeks pratci, p. 22, 38). У ст. 46 проекту Трудового кодексу України пропонується передбачити наслідки недійсності трудового договору або окремих його умов, що надасть додаткові гарантії для працівників щодо такої ситуащії. Так «недійсність окремих умов трудового договору не тягне за собою визнання недійсності трудового договору. У такому разі роботодавець зобов'язаний, за згодою працівника, внести до трудового договору відповідні зміни. Якщо сторони трудового договору не дійдуть згоди щодо зміни його умов, застосовуються норми трудового законодавства або колективного договору» (Proekt Kodeksu, p. 46). А отже, це змусить роботодавця в переговорах з трудовим колективом намагатись включення до умов колективного договору положень щодо можливості контролю за працівниками 3 використанням електронних засобів, а також щодо питань збирання, обробки, зберігання та використання отриманих під час такого контролю персональних даних працівників, як конфіденщійну інформацію про конкретну фізичну особу. 
Враховуючи природнє намагання та право роботодавців захищати свій бізнес, власність та конфіденщійну інформацію, практика ССПЛ підтверджує легальність їх спостереження за працівниками під час виконання тими трудових функцій (при попередньому попередження про таке спостереження), включаючи відеоспостереження, прослуховування, прочитання його робочої кореспонденщії тощо. I хоча дії щодо спостереження з боку роботодавця, у принципі, можуть визнаватись законними, бо тримають у «тонусі» весь трудовий колектив, але це не безмежно. Правові відносини щодо спостереження роботодавця за найманими працівниками пов 'язані із захистом та обробкою персональних даних останніх, і мають бути спрямованими на захист їхніх основоположних прав і свобод, зокрема права на невтручання в їхнє особисте життя, у зв' язку з обробкою персональних даних. Тож хазяйське (дисциплінарне) право роботодавця закінчується там, де такі дії починають зачіпати права та свободи працівників, тобто мають існувати його межі.

Водночас, роботодавцями можуть бути фізичні особи, що не мають статус підприємщів, але перебувають у трудових відносинах з працівниками для виконання ними домашньої роботи. Але ч.2 ст. 4 Закону № 2297-VI до володільців чи розпорядників персональних даних відносить лише фізичних осіб-підприємщів. Отже, для правомірного здійснення за такими працівниками відеоспостереження, прослуховування, технічного контролю за їхнім переміщенням тощо з боку таких фізичних осіб-роботодавців, а відтак, обробкою персональних даних цих працівників, вбачається логічним цю норму доповнити і зазначеною категорією роботодавців.

Таким чином, якою б метою не обгрунтовував, які б способи та засоби спостереження не застосовував роботодавець (відеоспостереження, включаючи приховане; записи телефонних розмов корпоративними телефонами; контроль за електронним листуванням та спілкуванням у соціальних мережах тощо), фактично, це є доступом, збиранням, обробкою, накопиченням та зберіганням, використанням, видаленням або знищенням, передачею персональних (особистих) даних працівника відповідно до Закону України «Про захист персональних даних» (далі - Закон № 2297-VI) ("Zakon Ukrainy", 2010, No 2297-VI). Ба більше, персональні дані працівника, отримані при такому спостереженні, є конфіденційною інформацією, оскільки це інформація про нього, як фізичну особу, а ії обробка без згоди цієї особи, згідно з цим законом, не допускається, крім випадків, чітко визначених правовою нормою.

Одночасно не вся інформація про фізичну особу є їі персональними даними, бо, відповідно до законодавства, це безпосередньо залежить від можливості ідентифікації. Так персональні дані працівника, як суб'єкта персональних даних, - це відомості чи сукупність відомостей про нього як фізичну особу, яка ідентифікована або може бути конкретно ідентифікована ("Zakon Ukrainy", 2010, No 2297-VI, p. 2). Тож якщо певна інформація дає змогу роботодавцю, як володільцю чи розпоряднику персональних даних, виділити із групи людей конкретну особу, то ії можна вважати персональними даними. Тому у випадку, коли дані, які самі собою не є персональними даними, але дають змогу ідентифікувати особу, стають персональними. І навпаки, якщо сукупність певних даних не дає змогу ідентифікувати особу, 
то їх обробка Законом № 2297-VI не захищається. Це твердження збігається з позицією, що викладена в п.26 Регламенту Свропейського Парламенту і Ради (ЄС) 2016/679, як головному документі ЄС, що скасував Директиву 95/46/ЄС (Загальний регламент про захист даних) та регулює захист прав фізичних осіб під час обробки їх персональних даних (включаючи дані, що були деперсоналізовані (стали анонімними). Так, згідно з цією нормою, «принципи захисту даних, відповідно, не можна застосовувати до анонімної інформації, зокрема інформащії, що не стосується фізичної особи (читай: «працівника» - abmор), яку ідентифіковано чи можна ідентифікувати, або персональних даних, що стали анонімними в такий спосіб, що суб'єкта даних неможливо чи білыше неможливо ідентифікувати. Таким чином, цей Регламент не стосується опрацювання такої анонімної інформації, у тому числі, для статистичних або дослідницьких цілей» (Reglament, 2016/679).

Відповідно до Рішення Конституційного Суду України, інформація про особисте життя особи (персональні дані про неї) - це будь-які відомості чи сукупність відомостей про фізичну особу, яка ідентифікована або може бути конкретно ідентифікована, заразом, відомості про події та явища, що відбувалися або відбуваються в професійному, діловому та інших сферах життя, а збирання, зберігання, використання та поширення конфіденційної інформації про особу без іï згоди є втручанням в ії особисте та сімейне життя Така інформація про фізичну особу та членів їі сім ї є конфіденційною і може бути поширена тільки за їх згодою, крім випадків, визначених законом, і лише в інтересах національної безпеки, економічного добробуту та прав людини (Rishenniy, 2-рп/2012).

Згідно з правовою позицією Верховного Суду, лише фізична особа, якої стосується конфіденційна інформація, відповідно до конституційного та законодавчого регулювання права особи на збирання, зберігання, використання та поширення конфіденційної інформації, має право вільно, на власний розсуд визначати порядок ознайомлення з нею інших осіб, держави та органів місцевого самоврядування, а також право на збереження їі в таємниці. Відповідно до ст. 14 Закону2297VI, встановлено, що поширення персональних даних передбачає дії щодо передачі відомостей про фізичну особу за згодою суб єкта персональних даних. Поширення персональних даних без згоди суб `кта персональних даних або уповноваженої ним особи дозволяється у випадках, визначених законом, і лише (якщо це необхідно) в інтересах національної безпеки, економічного добробуту та прав людини. Виконання вимог встановленого режиму захисту персональних даних забезпечує сторона, що поширює ці дані. Сторона, якій передаються персональні дані, повинна попередньо вжити заходів щодо забезпечення вимог цього Закону (Postanova, 804/4069/17).

Проте, важко уявити випадок, коли роботодавець (уповноважений ним орган чи посадова особа) не може ідентифікувати найманого ним працівника. До того ж, така ідентифікація найманого працівника прямо передбачена при укладанні трудового договору та вимогою щодо обов' язку працівника особисто виконувати доручену йому роботу (Kodeks pratci, p. 24, 30). Тож, як вбачається, інформація про найманого працівника, що отримана під час спостереження за ним, $є$ персональними даними про цю особу. 
Водночас, персональні дані і конфіденційна інформація, як інформації про особу найманого працівника, що одноосібно вирішує, яка з них є конфіденщійною чи відкритою, не є тотожними поняттями. Так, 3 аналізу законодавчих норм ("Zakon Ukrainy", 2011, p. 7), ("Zakon Ukrainy", 1992, p. 11, 21), ("Zakon Ukrainy", 2010, No 2297-VI, p. 2), не всі персональні дані $є$ конфіденщійною інформацією, бо деякі 3 них є відкритими, а до конфіденційної інформації належать не тільки персональні дані. Наприклад, відкритою (законодавством може бути заборонено віднесення певної інформації до обмеженої у доступі, зокрема і конфіденщійної) $є$ інформація про особисті дані певних категорій працівників ("Zakon Ukrainy", 2011, p. 6), ("Zakon Ukrainy", 2010, No. 2297-VI, p. 5). Тож конфіденційною є інформація про найманого працівника, що обмежена в доступі саме цією особою, а також попередньо обмежена законодавством до моменту відкриття особою такої інформації за ііі власним бажанням (згодою), з можливістю ії поширення у визначеному нею порядку відповідно до передбачених нею ж умов, а також в інших випадках, визначених законом (у т. ч. звички, включаючи, шкідливі; особливості поведінки та реакщії особи на щось, манери, стиль тощо).

Що стосується змісту терміна «персональні дані», то ССПЛ, схоже, на віміну від національного законодавства, не став спеціально вдаватися в докладний розгляд того, що саме входить до цього поняття, бо цілий шар даних, що стосуються осіб, може перебувати у відкритому доступі і належати до суспільного, а не до приватного життя особи (Rishennia ECHR, 2003). Згідно ж зі ст. 2 Закону № 2297VI, «персональні дані» - відомості чи сукупність відомостей про фізичну особу, яка ідентифікована або може бути конкретно ідентифікована, а особисті немайнові права на персональні дані, які має кожна фізична особа, є невід'ємними і непорушними (ч.1 ст. 8 Закону № 2297-VI).

ЄСПЛ обережніше ставиться до визначення цього поняття. Хоча у справі Кьопке (Köpke) проти Німеччини ЄСПЛ дійшов висновку: оскільки відеозапис про поведінку заявниці (працівниці) на своєму робочому місці був зроблений без ії попереднього повідомлення, отримане відео було оброблене та проаналізоване кількома особами, які працювали на роботодавця заявниці, крім того, вказане відео використовувалося у провадженнях з трудового спору, то вказані заходи могли зачіпати право заявниці на приватне життя в значенні п.1 ст. 8 Конвенщії. Водночас, у цьому ж рішенні вказано, що в майбутньому конкуруючі інтереси сторін цілком можуть бути оцінені по-іншому, беручи до уваги те, якою мірою втручання в приватне життя стане можливим завдяки новим, більш складним технологіям (Rishennia ECHR, 2010). Тому навіть ССПЛ визнає високу вірогідність перемоги «Старшого Брату» щодо легальності в подальшому тотального спостереження за найманими працівниками під час виконання ними трудових функцій.

Тож, згідно із сучасною позищією ЄСПЛ, а відтак джерела права щодо регулювання трудових відносин в Україні, кожна людина має право на особисту зону, тобто на приватність, у т.ч. і в момент виконання трудових обов'язків (справа «Ганновер проти Німеччини» (Rishennia ECHR, 2004).

До того ж, такий контроль за працівниками не може здійснюватись, якщо ті працюють дистанційно, а їхнім робочим місцем є власне житло, бо це прямо про- 
тирічить ст. 30 (недоторканість житла) та ст. 32 (втручання в сімейне життя) Конституції України. Зазначені види відеоспостереження, безумовно, є зазіханням на особисту зону працівника, а тому порушує його право на приватне (особисте) життя (Konstytutsiia, p. 30, 32).

Право найманого працівника на свою приватну сферу, включаючи дані, отримані роботодавцем під час спостереження за ним, абсолютне (бо це є таємницею його приватного життя, оскільки кожна особа має право вимагати від необмеженого кола осіб обов'язкової заборони на збирання вказаних відомостей, а якщо ці відомості стали відомими особі у зв'язку з їі професійною діяльністю, то - нерозголошення).

Отже, кожен найманий працівник під час виконання трудових функцій і здійснення спостереження за цим процесом, а відтак, обробки його персональних даних, у період збирання інформації, але до початку ії використання, має право: знати хто саме, у який спосіб, з якою метою та які саме відомості про нього збираються, використовуються, передаються чи поширюються; вимагати виправлення неточної, неповної, застарілої інформації про себе; знищення інформації про себе, збирання, використання чи зберігання якої здійснюється з порушенням вимог законодавства. А відтак, закон, перш за все, надає працівнику захист від розголошення певній, здебільшого чутливій, інформащії навіть до обмеження доступу до неї фізичною чи юридичною особою, тим самим припускаючи бажання особи обмежити доступ до такої інформації саме через ії «чутливість», до того ж, у самого працівника зберігається право прийняти рішення про розкриття цієї інформації та не обмежувати надалі доступ до неї» (Komentar zakonu, p. 122-126).

Показовою є позиція Верховного Суду, який зазначав, що, встановивши при вирішенні таких спорів факт поширення інформації про приватне життя позивача, що відповідає дійсності та не порочить його гідність, честь чи ділову репутацію, а також факт відсутності згоди позивача на поширення цієї інформації, суд повинен захистити його право на таємнищю приватного життя та може зобов'язати відповідача відшкодувати моральну шкоду. Судам слід ураховувати положення ч.11 ст. 30 Закону України «Про інформацію», у якій зазначено, що інформацію з обмеженим доступом може бути поширено без згоди ії власника, якщо ця інформація є суспільно значимою, тобто якщо вона є предметом громадського інтересу і якщо право громадськості знати цю інформацію переважає право їі власника на їі захист, що відповідає практищі застосування Свропейським судом з прав людини ст. 8 Конвенщії (Postanova Plenumu, 2009).

Тож поняття приватного життя (особистої зони) працівників у момент виконання ними трудових обов'язків тлумачитися не в обмежувальному значенні, а відтак, навпаки, в обмежувальному значенні щодо можливого обсягу та характеру персональних даних про них під час здійснення контролю за їхньою роботою 3 боку роботодавців (обробки персональних даних). Як убачається, приватне життя найманого працівника - це особлива частина приватної сфери його людської життєдіяльності (приватна зона), у т.ч. час виконання ним трудових функцій, яка полягає в різноманітних відносинах, стосунках, явищах, подіях, поведінці тощо, що 
не мають публічного значення, включаючи сферу його праці, визначається і регулюється ним самим. А отже, зняття роботодавцем інформації з транспортних телекомунікаційних та електронних інформаційних мереж, публічні та приховані відеоспостереження на робочому місті й прослуховування телефонних розмов корпоративними телефонами, контроль за електронним листуванням та спілкуванням працівників у соціальних мережах тощо, це, щонайменше, збирання, зберігання та використання інформащії про особисту частину життя пращівника, тобто, персональні дані такої особи, що може становити недозволене втручання в iї особисте життя. А щоб таке втручання було законним, воно повинно відбуватися за згодою конкретного працівника.

Що ж визнається згодою працівника, дає відповідь положення ст. 2 Закону № 2297-VI: «згода суб'єкта персональних даних» - це добровільне волевиявлення фізичної особи щодо надання дозволу на обробку іï персональних даних відповідно до сформульованої мети їх обробки, висловлене в письмовій формі або у формі, що дає змогу зробити висновок про надання згоди. Тобто, усі види спостереження мають здійснюватися за згодою працівника, бо підпадає під норми Закону № 2297-VI, в іншому випадку воно є незаконним. Згода ж на спостереження за допомогою технічних засобів може бути: (1) ясно виражена (письмова) - пріоритетніше; (2) усне, що є проблемнішим з доказового аспекту; (3) мовчазне, коли, наприклад, упродовж роботи працівник бачить камери, але не заперечує. Перший спосіб є найприйнятнішим, унаслідок положень ст. 29 КЗпП України, які зобов'язують роботодавця до початку роботи за укладеним трудовим договором проінформувати працівника під розписку про умови його праці та вимоги на робочому місці, як і способи контролю щодо його виробничої діяльності. Хоча існує й думка, що таке спостереження не є умовою праці, а тому застосовувати при його впровадженні правила ст. 32 (зміна істотних умов праці) та/або ст. 29 КЗпП України не потрібно (Kodeks pratsi, p. 32, 29).

Висновки. Підсумовуючи, зазначимо, що Україна, як правова держава, має забезпечити дотримання своїх міжнародних зобов'язань, зокрема у сфері трудових прав людини, у т.ч. захист найманих працівників від свавілля роботодавців при здійсненні ними контролю за працівниками з використанням технічних засобів, та пов' язану з цим обробку їхніх персональних даних.

Правове регулювання захисту персональних даних працівників, отриманих, зокрема, під час погоджених із ними записів їхніх телефонних розмов; контролю за їхнім електронним листуванням та спілкуванням у соціальних мережах; відеоспостереження тощо щодо їх збирання, обробки та оприлюднення, потребують розвитку, зважаючи на досвід країн Свропейського Союзу, які переважно пройшли шлях створення ефективного механізму щодо забезпечення права працівників на особисту зону під час виконання ними трудових функцій. Досліджена практика ССПЛ дозволяє вже зараз регулювати в Україні зазначені відносини між роботодавцями та працівниками щодо забезпечення права останніх на приватне життя та захист їхніх персональних даних. Заразом, без якісного врегулювання зазначених правовідносин на державному рівні, є ризики виникнення значної кількості спорів (конфліктів) щодо порушення прав працівників, у тому числі, і щодо 
захисту їхніх персональних даних, що й потребує вирішення на законодавчому та локальному рівнях.

Враховуючи, що роботодавцем, як володільцем чи розпорядником персональних даних, можуть бути не тільки фізичні особи, що мають статус підприємщів, наприклад, у випадку трудового найму працівника для виконання домашньої роботи та здійснення за ним відеоспостереження, прослуховування, технічного контролю за їхнім переміщенням тощо фізичною особою-роботодавцем, ч.2 ст. 4 Закону України «Про захист персональних даних» від 01.06.2010 року № 2297-VI пропонується викласти в наступній редакції:

«2. Володільцем чи розпорядником персональних даних можуть бути підприємства, установи й організації всіх форм власності, органи державної влади чи органи місцевого самоврядування, фізичні особи, включаючи фізичних осіб - підприємців, які обробляють персональні дані відповідно до закону».

Статтю 2 КЗпП України «Основні трудові права працівників» доповнити частиною 3, яка б передбачала додаткові гарантії захисту права працівників на повагу до їхнього приватного життя та таємницю особистих листування, спілкування в електронних інформаційних мережах, телефонних розмов, електронної та іншої кореспонденції.

Частину 1 статті 29 проекту Трудового кодексу України доповнити абзацем 2, виклавши його в наступній редакції: «Під час здійснення контролю не допускаються збір, зберігання та оприлюднення інформації про особисте (приватне) життя працівників без їхньої письмової згоди. Перелік такої конфіденційної інформації встановлюється законодавством».

Тож наукова новизна публікації полягає в тому, що питання правомірності контролю роботодавця за працівником з використанням технічних засобів комплексно досліджено з огляду на їх види, вимоги законодавста, включаючи практику ССПЛ та національну судову практику. Зазначене вимагає ретельного дослідження нормативного регулювання технічного контролю роботодавців за працівниками із застосуванням зняття інформації з транспортних телекомунікаційних та електронних інформаційних мереж, відеоспостереження і прослуховування, контролем за електронним листуванням та спілкуванням осіб у соціальних мережах. Дослідженням обгрунтовується необхідність нормативного визначення в законодавстві України можливих меж обмеження прав і свобод працівників на їхнє приватне життя (приватності їхньої особистої зони під час виконання ними трудових функцій), як-от, втручання хазяйської (дисциплінарної) влади роботодавця в цю сферу приватної автономії найманих ним працівників.

\section{Використані джерела:}

1. Оруэлл Дж. 1984 / пер. с англ. Гольшева В. П. Санкт Петербург : Азбука, 2004. 320 с.

2. Про боротьбу з терроризмом : Закон України від 20.03.2003 року № 638-IV. Bidoмості Верховної Ради України (ВВР), 2003, № 25, ст. 180.

3 Про встановлення карантину та запровадження обмежувальних протиепідемічних заходів з метою запобігання поширенню на території України гострої респіраторної хвороби COVID-19, спричиненої коронавірусом SARS-CoV-2 : постанова Кабінету Міні стрів України від 09.12.2020 року № 1236. URL : https://www.kmu.gov.ua/npas/pro- 
vstanovlennya-karantinu-ta-zaprovadzhennya-obme zhuvalnih-protiepide michnih-zahodiv1236-091220. (дата звернення: 10.03.2021)

4. Рада Європи. Рішення ССПЛу справі «Ганновер проти Німеччини» (Hannover v. Germany) від 24.06.2004 року. (заява № 59320/00). URL : https://zakon.rada.gov.ua/laws/ show/980_324\#Text. (дата звернення: 10.03.2021)

5. Нестерович В. Ф. Заборона дискримінації як важливий міжнародний та конституційний принцип в галузі прав людини. Експерт: парадигми юридичних наук $і$ державного управління. 2020. № 5. С. 86-122.

6. Кодекс законів про працю України : Закон України від 10.12.1971 року № 332-VIII. Відомості Верховної Ради УРСР. 1971. Додаток до № 50. Ст. 375.

7. Конвенщія про захист прав людини і основоположних свобод від 04.11.1950 року, в редакції від 02.10.2013 року. URL : https:/ /zakon.rada.gov.ua/laws/show/995_004. (дата звернення: 10.03.2021)

8. Конвенщія про захист осіб у зв'язку автоматизованою обробкою персональних даних від 28.01.1981 року. Додатковий протокол від 08.11.2001 року. URL : https:/ zakon. rada.gov.ua/laws/show/994_326\#Text. (дата звернен ня: 10.03.2021)

9. Хартія основних прав Европейського Союзу від 07.12.2000 року. URL : https:// zakon.rada.gov.ua/laws/show/994_524\#Tехt. (дата звернення: 10.03. 2021)

10. Конституція України : Закон України від 28.06.1996 року № 354к/96-ВР. Відомості Верховної Ради Украӥни. 1996. № 30. Ст. 141.

11. Цивільній кодекс України : Закон України від 16.01.2003 року № 435-IV. Biдомості Верховної Ради Украӥни (ВВР), 2003, №№ 40-44, ст. 356.

12. Ваганова I. М. До питання про використання технічних засобів спостереження у трудовому праві України. Тенденції розвитку науки трудового права та права социіального забезпечення: тези доп. та наук. повідомл. учасн. II Міжнар. наук.-практ. конф. (м. Київ, 2122 квітня 2016 р.) / за ред. проф. М. І. Іншина, проф. В. І. Щербини, відпов. ред. к.ю.н. І. С. Сахарук. Київ : Прінт-Сервіс, 2016. С. 39-43.

13. Про міжнародні договори України : Закон України від 29.06.2004 року № 1906IV. Відомості Верховної Ради України (ВВР), 2004, № 50, ст. 540.

14. Про виконання рішень та застосування практики Європейського суду з прав людини : Закон України від 23.02.2006 року № 3477-IV. Відомості Верховної Ради України (BВP), 2006, № 30, ст. 260.

15. Рада Європи. Рішення ЄСПЛ від 28.01.2003 року по справі «Пек проти Сполученого Королівства» (Peck v. the United Kingdom, № 44647/98, ECHR 2003). URL : https:// zakon.rada.gov.ua/laws/show/980_165\#Text.

16. Рада Європи. Рішення ЄСПЛ у справі Німіц проти Німеччини [Niemietz v. Germany], від 16.12.1992 року, § 29, Серія А, № 251-B, заява № 13710/88. URL : http:// search.ligazakon.ua/1_doc2.nsf/link1/SO2132.html. (дата звернення: 10.03.2021)

17. Лазор I. В. Дисциплінарна влада роботодавця: поняття та значення в умовах $p u$ нкових відносин. Держава і право. Випуск 52. Юридичні і політичні науки. 2011. С. 315-321. URL : http://dspace.nbuv.gov.ua/bitstream/handle/123456789/34040/52-Lazor.pdf? Seque nce=1. (дата звернення: 10.03.2021)

18. Проект Трудового кодексу України № 1658 від 27.12.2014 року, включено до порядку денного до другого читання 24.07.2017 року № 2679-VIII. URL : https:/ / w1.c1. rada. gov.ua/pls/zweb2/webproc4_1?pf3511=53221. (дата звернення: 10.03.2021)

19. Регламент Свропейського Парламенту і Ради (СС) 2016/679 від 27.04.2016 року про захист фізичних осіб у зв'язку з опра цюванням персональних даних і про вільний 
рух таких даних, та про скасування Директиви 95/46/СС (Загальний регламент про захист даних). URL : https:/ /zakon.rada.gov.ua/laws/show/984_008-16\#Tехt. (дата звернен ня: 10.03.2021)

20. Про доступ до публічної інформації : Закон України від 13.01.2011 року № 2939VI. Відомості Верховної Ради України (ВВР), 2011, № 32, ст. 314.

21. Про інформацію : Закон України від 02.10.1992 року № 2657-ХII. Відомості Верховної Ради України (ВВР). 1992. № 48. Ст. 650.

22. Про захист персональних даних : Закон України від 01.06.2010 року № 2297-VI. Відомості Верховної Ради України (ВВР), 2010, № 34, ст. 481.

23. Рада Європи. Рішення ЄСПЛ у справі Кьопке (Kőpke) проти Німеччини Кӧрke v. Germany (dec.), no. 420/07, 5 October 2010. URL : http://hudoc.echr.coe.int/eng?i=001101536. (дата звернення: 10.03.2021)

24. Науково-практичний коментар до Закону України «Про доступ до публічної інформації. Центр суспільних медіа за підтримки Міжнародного фонду «Відродження» та Програми сприяння Парламенту. За заг. ред. Д Котляра. Київ, 2012. 335 с.

25. Постанова Верховного Суду України «Про судову практику у справах про захист гідності та честі фізичної особи, а також ділової репутації фізичної та юридичної особи» від 27.02.2009 року № 1. URL : https:/ / zakon.rada.gov.ua/laws/show/v_001700-09\# Text. (дата звернення: 10.03.2021)

26. Рішення Конституційного Суду України у справі за конституційним поданням Жашківської районної ради Черкаської області щодо офіційного тлумачення положень частин першої, другої статті 32, частин другої, третьої статті 34 Конституції України від 20.01.2012 року № 2-рп/2012 у Справі № 1-9/2012. URL : https://zakon.rada. gov.ua/ laws/show/v002p710-12\#Text. (дата звернення: 10.03.2021)

27. Постанови Верховного Суду від 16.04 .2020 року у справі № 804/4069/17. URL : https:/ / zakononline.com.ua/court-decisions/ show/88815240. (дата звернення: 10.03.2021)

\section{References:}

1. Oruell, Dzh. 1984. (2004) / per. s angl. of Golysheva V. P. Sankt Petersburg : Alphabet. [in Russian].

2. Zakon Ukrainy "Pro borotbu z terorizmom" : vid 20 berezn. 2003 r. No. 638-IV. (2003) Vidomosti Verkhovnoi Rady Ukrainy - Bulletin of the Verkhovna Rada of Ukraine (BBR), 25, art. 180. [in Ukrainian].

3. Postanova Kabinetu Ministriv Ukrainy "Pro vstanovlennye karantinu ta zaprovadzhenny obmezhuvalnih protiepidemichnih zahodiv z metuy zapobiganniy poshirennyu na teritoriiy Ukrainy gostroy respiratornoy hvorobi COVID-19, sprichinenoy koronavirusom SARS-CoV-2": vid 9 grud. 2020 r. No 1236. (2020). N. p. URL : https://www.kmu.gov.ua/ npas/-1236-091220. [in Ukrainian].

4. Rada Evropy. Rishenny ECHR u spravi "Hannover proty Nimetchiny" 24 cherv. 2004 r. No 59320/00. (2004) N. p. URL : https://zakon.rada.gov.ua/laws/show/980_324\#Text. [in Ukrainian].

5. Nesterovych, V.F. (2020) Zaborona dyskryminatsiyi yak vazhlyvyy mizhnarodnyy ta konstytutsiynyy pryntsyp v haluzi prav lyudyny. Ekspert: paradyhmy yurydychnykh nauk $i$ der zhavnoho upravlinnya - Expert: paradigms of legal sciences and public administration, 5, 86-122. [in Ukrainian].

6. Zakon Ukrainy "Kodeks zakoniv pro pracyu Ukrainy" : vid 10 grudn. 1971 r. No 332VIII. (1971) Vidomosti Verkhoonoi Rady Ukrainy - Bulletin of the Verkhoona Rada of Ukraine, Addition No. 50, art. 375. [in Ukrainian]. 
7. Konvensiy pro zahist prav lyuduni I osnovopolozhnih svobod: mizhnar. dok. vid 23 list. 1950 r., v redaksiy 2 zhovt. 2013. (2013) N. p. URL : https://zakon.rada.gov.ua/laws/ show/995_004. [in Ukrainian].

8. Hartiy osnovnih prav Evropeyskogo Soyuzu vid 07 grudn. 2000 r. (2000) N. p. URL : https://zakon.rada.gov.ua/laws/show/ 994_524\#Text. [in Ukrainian].

9. Konvensiy pro zahist osib u zv`yzku avtomatizovanoyu obrobkoyu personalnih danih vid 28 sihn. 1981 r. (1981) URL : https:// zakon.rada.gov.ua/laws /show/994_326\#Text. [in Ukrainian].

10. Konstytutsiia Ukrainy: vid 28 cherv. 1996 r. No 254k/96-VR. (1996) Vidomosti Verkhoonoi Rady Ukrainy - Bulletin of the Verkhoona Rada of Ukraine, 30, art. 141. [in Ukrainian].

11. Zakon Ukrainy " Civilniy codeks Ukrainy" : vid 16 sich. 2003 r. No 435-IV. (2003) Vidomosti Verkhovnoi Rady Ukrainy - Bulletin of the Verkhovna Rada of Ukraine, 40-44, art. 356. [in Ukrainian].

12. Vaganova, I. M. (2016). Do pitanny vikoristanny tehnichnih zasobiv sposterezhenny u trudovomu pravi Ukrainy. Tendentsii rozvytku nauky trudovoho prava ta prava sotsialnoho zabezpechennia : tezy dop. ta nauk. povidoml. uchasn. II Mizhnar. nauk.-prakt. konf. (m. Kyiv, 21-22 kvitnia 2016 r.) Progress of science of labour right and right for public welfare trends: theses of dop. but sciences. povidoml. uchasn. II Mizhnar. sciences.-pract. konf. (m. Kyiv, on April, 21-22 in 2016) / M. Inshina, prof. B. Scherbini (Eds.), I. Sakharuk (Ed.). Kyiv : Print-service, 39-43. [in Ukrainian].

13. Zakon Ukrainy "Pro mizhnarodni dogovory" vid 29 chervn. 2004 r. No. 1906-IV. (2004) Vidomosti Verkhovnoi Rady Ukrainy - Bulletin of the Verkhovna Rada of Ukraine (BBR), 50, art. 540. [in Ukrainian].

14. Zakon Ukrainy "Pro vikonanniy risheny ta zastosuvanniy praktiki Evropeyskogo sudu z prav lyudini vid 23 lyut. 2006 r. (2006) Vidomosti Verkhovnoi Rady Ukrainy - Bulletin of the Verkhovna Rada of Ukraine (BBR), 30, art. 260. [in Ukrainian].

15. Rada Evropy. Rishenny ECHR u spravi "Peck proty The United Kingdom" 28 sichn. 2003 r. No 44647/98. (2003) N. p. URL: https://zakon.rada.gov.ua/laws/show/980_165\# Text. [in Ukrainian].

16. Rada Evropy. Rishenny ECHR u spravi "Niemietz proty Germany" 16 grud. $1992 \mathrm{r}$. No 13710/88. (1992) N. p. URL : http://search.Li gazakon.ua/1_doc2.nsf/ link1/SO2132.html. [in Ukrainian].

17. Lazor, I. V. (2011). Dusciplinarna vlada robotodavcy: poniyttiy ta znachenniy v umovah runkovuh vidnosin. Derzhava I parvo. Yuridichni I politichni naukiy - State and right. Legal and political sciences, issue 52, 315-321. URL : http://dspace.nbuv.gov.ua/bitstream/handle/ 123456789/ 34040/ 52-Lazor.pdf?sequence=1. [in Ukrainian].

18. Proekt Trudovogo kodeksu Ukrainy 27 grudn. 2014 No 1658, vklyucheno do poryad ku dennogo do drugogo chitanny 24 lipn. 2017. (2017) N. p. URL : https:/ / w1.c1.rada. gov.ua/ pls/zweb2/webproc4_1?pf3511=53221. [in Ukrainian].

19. Reglament Yevropeiskoho Parlamentu i Rady (IeS) 2016/679 vid 27.04.2016 roku pro zakhyst fizychnykh osib u zviazku z opratsiuvanniam personalnykh danykh i pro vilnyi rukh takykh danykh, ta pro skasuvannia Dyrektyvy 95/46/IeS (Zahalnyi rehlament pro zakhyst da nykh). (2016) N. p. URL: https://zakon.rada.gov.ua/laws/show/984_008-16\#Text. [in Ukrainian].

20. Zakon Ukrainy "Pro dostup do publichnoyi informaciy" : vid 13 sich. 2011 r. № 2939VI. (2011) Vidomosti Verkhoonoi Rady Ukrainy - Bulletin of the Verkhoona Rada of Ukraine (BBR), 32, art. 314. [in Ukrainian].

21. Zakon Ukrainy "Pro informaciy": vid 2 zhovt. 1992 r. No. 2657-XII. (1992) Vidomosti Verkhoonoi Rady Ukrainy - Bulletin of the Verkhorna Rada of Ukraine (BBR), 48, art. 650. [in Ukrainian]. 
22. Zakon Ukrainy "Pro zahist personalnih danih": vid 1 cherv. 2010 r. No 2297-VI. (2010) Vidomosti Verkhovnoi Rady Ukrainy - Bulletin of the Verkhovna Rada of Ukraine (BBR), 34, art. 481. [in Ukrainian].

23. Rada Evropy. Rishenny ECHR u spravi "Köpke proty Germany" 5 zhovt. 2010 r. No. 420/07. (2010) N. p. URL : http:/ / hudoc.echr.coe.int/eng?i=001-101536. [in Ukrainian].

24. Naukovo-praktichniy komentar do Zakonu Ukrainy "Pro dustup do publihnoy informaciy". (2012) Center publichnih media. / D. Kotlyar (Ed.) Kyiv. [in Ukrainian].

25. Postanova Verhovnogo Sudu Ukrainy "Pro sudovu praktiku u spravah pro zahist gidnosti ta chesti fizichnoy osobi, a takzhe dilovoy reputaciy fizichnoy ta yuridihnoy osobi" : vid 27 Lyut. 2009 r. No 1. (2009) N. p. URL : https://zakon.rada. gov.ua/laws/show/v_00170009\#Text. [in Ukrainian].

26. Rishenniy Konstituciynogo Sudu Ukrainy u spravi za konstituciynim podonniym Zhashkivskoy rayonnoy radi Cherkaskoy oblasti shodo oficiynogo tlumachenniy polozheny chasten pershoy, drugoy statty 32, chasten drugoy, tretyoy statty 34 Konstitucii vid sihn. 20, 2012 r. No 2-pп/2012. (2012) N. p. URL : zakon.rada.gov.ua.Retrieved from https://zakon. rada.gov. ua/laws/show/v002p710-12\#Text. [in Ukrainian].

27. Postanova Verhovnogo Sudu vid 16 kvitn. 2020 r. u spravi No 804/4069/17. (2020) N. p. URL: https://zakononline.com.ua/court-decisions/show/88815240. [in Ukrainian].

Стаття надіӥшиа до редколегї 12.03.2021

Кравченко И. М., кандидат юридических наук, доцент кафедры государственно-правовых дисииплін Луганского государственного университета внутренних дел имени Э. А. Дидоренко, адвокат (г. Северодонеик, Украина)

\section{ПРОБЛЕМЫ ПРАВОВОГО РЕГУЛИРОВАНИЯ КОНТРОЛЯ РАБОТОДАТЕЛЯМИ НАЕМНЫХ РАБОТНИКОВ С ПРИМЕНЕНИЕМ ТЕХНИЧЕСКИХ СРЕДСТВ С УЧЕТОМ ЗАЩИТЫ ИХ ПЕРСОНАЛЬНЫХ ДАННЫХ}

На основании анализа норм национального законодательства национальной судебной практики и практики ЕСПЧ в статье дана правовая характеристика понятия «защита персональных данных» относительно допустимости границ ограничения конституционных прав и свобод работников на их частную жизнь при осуществлении работодателем контроля за выполнением ими трудовых функций с применением технических средств и способов.

Также изучен вопрос возможности нормативного определения возможных пределов ограничения прав и свобод работников на частную жизнь при выполнении своих трудовых функций.

Определено, что эффективная защита права работников на частную жизнь (приватности личной зоны во время выполнения ими трудовых функций), защита его персональных данных не возможна без его нормативного регулирования с использованием практики ЕСПЧ.

Ключевые слова: работодатель; наёмный работник; рабочее место работника; видеонаблюдение; прослушивание работника; контроль личной корреспонденции; персональные данные; конфиденциальная информация; обработка персональных данных; правомерное ограничение прав и свобод граждан. 
Kravchenko I., Candidate of Law, Associate Professor of the Department of State Law, Luhansk State University of Internal Affairs named after E. Didorenko, Lawyer (Sievierodonetsk, Ukraine)

\section{PROBLEMS OF LEGAL ADJUSTING CONTROL OF THE HIRED WORKERS EMPLOYERS WITH HARDWARE APPLICATION FROM VIEW OF THEIR PERSONAL DATA PROTECTION}

On the basis of analysis of norms of national legislation, national judicial practice and practice of ESPL, legal description of concept «protection of the personal data» is given in relation to admission of limits of limitation of constitutional rights and freedoms of workers on their private life at realization of control an employer with application of hardwares and methods after implementation by them labour functions. The question of possibility of normative determination of possible limits of limitation of rights and freedoms of workers is studied on private life pidchas by implementation of the labour functions.

The purpose of the article is establishment of possibility of application in Ukraine to the labour legal relationships of practice of ESPL in relation to a zabezpechennosti right on private life.

The scientific novelty of publication consists in that question of legitimacy of control of employer after a worker with the use of hardwares complex investigational taking into account their kinds, requirements of zakonodavsta, including a practical worker ESPL, and national judicial practice.

The article of research is ground the necessity of the normative fixing for the legislation of Ukraine of possible limits of limitation of rights for workers, for example interference of proprietary (disciplinary) power of employer with a sphere them private autonomy.

It is determined that effective protection of employees' right to privacy (privacy of their personal area during the performance of their labor functions), protection of his personal data, is not possible without its regulation using the practice of the ECHR.

Keywords: employer; hired worker; workplace of worker; videosupervision; listening of worker; control of the personal correspondence; personal information; confidential information; processing of the personal data; legitimate limitation of rights and freedoms of citizens. 